\title{
The Effect of Free Cash Flow, Debt to Equity Ratio, Working Capital Turnover and Earnings Per Share on Stock Prices with Stock Beta as Moderating Variable in Construction Sub-Sector Companies Listed on the IDX for the 2013-2019 Period
}

\author{
Nurul Ramadhani Pauzi Harahap ${ }^{1}$, Idhar Yahya', Abdillah Arif Nasution ${ }^{1}$ \\ ${ }^{1}$ Department of Accounting, Faculty of Economics and Business at Universitas Sumatera Utara, Indonesia
}

Corresponding Author: Nurul Ramadhani Pauzi Harahap

\begin{abstract}
The purpose of this study aims to discover the effect of free cash flow, debt to equity ratio working capital turnover, and earning per share on stock price with stock beta as moderating variables.

This research was conducted on Construction Sub-Sector Companies listed on the Indonesia Stock Exchange for 2013-2019.

The technique in this study uses a purposive sampling technique. The sampling technique shows that the research sample is ten companies with seven years of research, so the number of observations in this study is 70. The data analysis method used in this study is Panel Data Regression Analysis which was carried out with the help of EViews software.

The results showed that free cash flow, working capital turnover did not significantly affect stock prices and earnings per share, and the debt to equity ratio had a significant effect on stock prices. The stock beta variable can moderate the effect of free cash flow, debt to equity ratio, working capital turnover, and earnings per share on stock prices.
\end{abstract}

Keywords: Free Cash Flow, Working Capital Turnover, Earnings Per Share and Debt to Equity Ratio, Stock Price and Stock Beta

\section{INTRODUCTION}

In the business world in Indonesia, the capital market has a crucial position because it is one of the crucial elements in national economic development. Even the capital market is used as an indicator for the economic development of a country. The capital market is a means to obtain funds from the public (investors) who want to invest in all sectors on the Indonesia Stock Exchange. Some capital market attractions include the capital market, allowing investors to have various alternative investment options according to their risk preferences. Meanwhile, for companies that need funds, the capital market can be an alternative option for external funding with relatively low costs from the banking system.

The capital market in Indonesia collects funds from the public (investors) through the sale and purchase of stock prices. According to Darmadji and Fakhruddin (2012), shares can be defined as a sign of participation or ownership of a person or legal entity in a company or limited liability company. The stock market price in the secondary market is determined by the strength of supply and demand for shares. So the stock price will fluctuate depending on which one is stronger. If the demand is stronger than the supply, then the stock price will go up, but if the supply is stronger than the demand, the stock price will decrease. 
Nurul Ramadhani Pauzi Harahap et.al. The effect of free cash flow, debt to equity ratio, working capital turnover and earnings per share on stock prices with stock beta as moderating variable in construction subsector companies listed on the IDX for the 2013-2019 period.

Stock prices are influenced by several primary factors, namely internal factors, and external factors. Internal factors, also known as fundamental factors, originate from within the company and can be controlled by company management. This internal factor is related to the income obtained by investors in the form of dividends and capital gains.

External factors are nonfundamental factors, usually macro, such as legal and political conditions, inflation, changes in currency exchange rates, and fluctuations in bank interest rates. These factors will affect public demand and supply for shares traded in the capital market.

One of the external factors that affect stock prices is free cash flow. Free cash flow reflects the company's flexibility in making additional investments, paying off debt, buying treasury shares, or adding liquidity. White et al. (2003) define free cash flow as discretionary cash flow available to the company. So that high free cash flow indicates high company performance. The company's high performance will increase shareholder value, manifested in high returns through the development of share prices, dividends, or retained earnings to be invested in the future. Ramadhan (2016) suggests that free cash flow should be distributed as dividends. When the cash is distributed as dividends, it will be a positive signal for investors so that the signal will affect the demand for the company's shares, which will affect the stock price. However, companies usually prefer to reinvest the cash in other projects to generate profits (profitability).

Another external factor that influences stock prices is the debt to equity ratio. Debt to Equity Ratio (DER) is a market ratio used to compare the company's debt and equity. Kasmir (2008) states that DER is a ratio used to assess total debt to total equity. This ratio helps know the number of funds provided by creditors with company owners. A high DER number leads to an increased risk. High risk is expected to provide high profits as well. It is a consideration for investors in buying or selling shares. However, with a higher level of risk, investors will bid the stock at a low price because investors generally avoid risk. In addition, a high DER illustrates that the company's debt is greater than capital. It is a negative signal for potential investors and shareholders because it means that the interest costs paid to pay debts to creditors will be enormous and cause the company's net profit to decline. A decrease in net income will cause a decrease in stock prices.

Other external factors that affect stock prices apart from free cash flow and debt to equity ratio are earnings per share and working capital turnover. Earnings per share (Earning Per Share) is the amount of net income on each share of common stock (Hery, 2009). Earnings per share is an indicator of earnings that investors pay attention to, which generally has a strong correlation between earnings growth and stock price growth (Muiz, 2016). Generally, high earnings per share indicate better profitability than low earnings per share. It means that the company can generate higher profits to be distributed to its shareholders. However, investors pay attention to the value of this per share to buy shares or not in the company concerned. Tandelilin (2001) argues that "If the company's profit is high, investors will be interested in buying the shares, so that the share price will increase." From the explanation above, it can be seen that the relationship between Earning Per Share and stock market prices are very close.

According to Kasmir (2011), working capital is working capital defined as investments invested in current assets or short-term assets, such as cash, banks, securities, receivables, inventories, and other current assets. Working capital turnover can facilitate the operations of a company to obtain optimal profits. Therefore, companies need funds to obtain working capital. One of them is by selling shares to the public in a current financial position. If the company can generate net 
Nurul Ramadhani Pauzi Harahap et.al. The effect of free cash flow, debt to equity ratio, working capital turnover and earnings per share on stock prices with stock beta as moderating variable in construction subsector companies listed on the IDX for the 2013-2019 period.

income continuously for the future, then creditors can judge that the company's financial performance is good, and automatically share prices will rise.

On the other hand, if the company makes a loss, the stock price will fall. Working capital turnover is one of the ratios to measure or assess the effectiveness of the company's working capital during a specific period. It means how much working capital rotates during a period or in a period. If the working capital turnover is low, it means that the company has excess working capital. It is due to low inventory turnover or too large a cash balance receivable. Vice versa, if the working capital turnover is high, it may be due to the high turnover of receivables inventory or the cash balance is too small. The working capital turnover period occurs when cash is used for company operations until the cash returns to cash.

According to Fabozzi and Francis (1979), beta is a systematic risk index of an asset or a portfolio. Beta measures the sensitivity of asset returns to market portfolio returns. The relevant risk to be considered in investment in the form of a portfolio is systematic risk, where the size of the beta unit indicates the size of the risk. The size of the beta indicates the size of the sensitivity of changes in the profit rate of Rit's shares to changes in the market profit rate of Rmt. Knowing the beta of a security is vital for analyzing the security. Beta can be used to compare the relative systematic risk of different stocks, so investors can use it to estimate the risk of a stock. Stocks can be ordered by beta. Because market variance can be fixed for all securities over a given period, stocks based on beta are the same as ordering based on the absolute value of their systematic risk. Stocks with high beta are said to have risk, and conversely, stocks with low beta are said to have low risk.

This study uses construction subsector companies listed on the Indonesia Stock Exchange for the period 2013-2019. The following is a phenomenon in this study that the author studied.

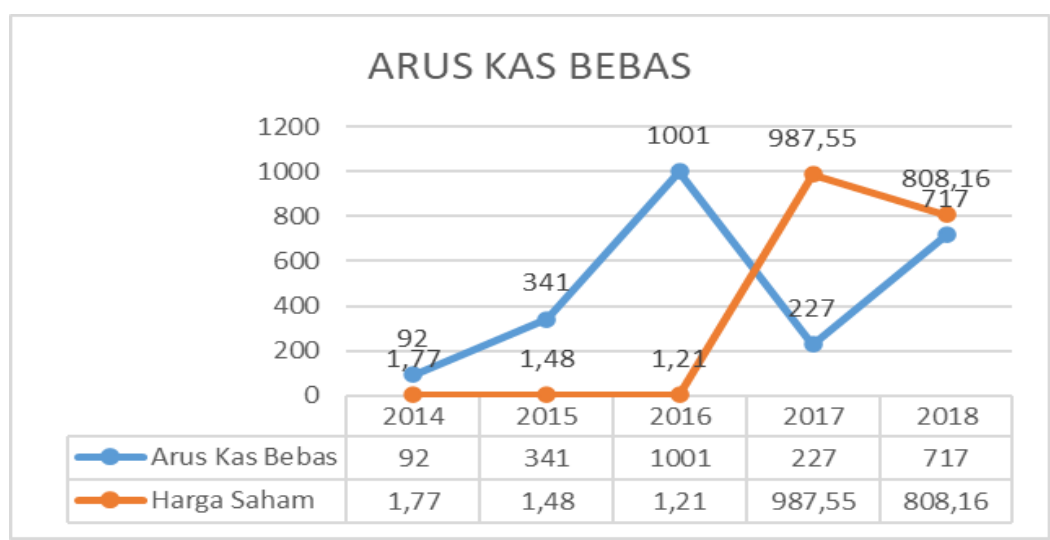

Figure 1.Free Cash Flow to Stock Price

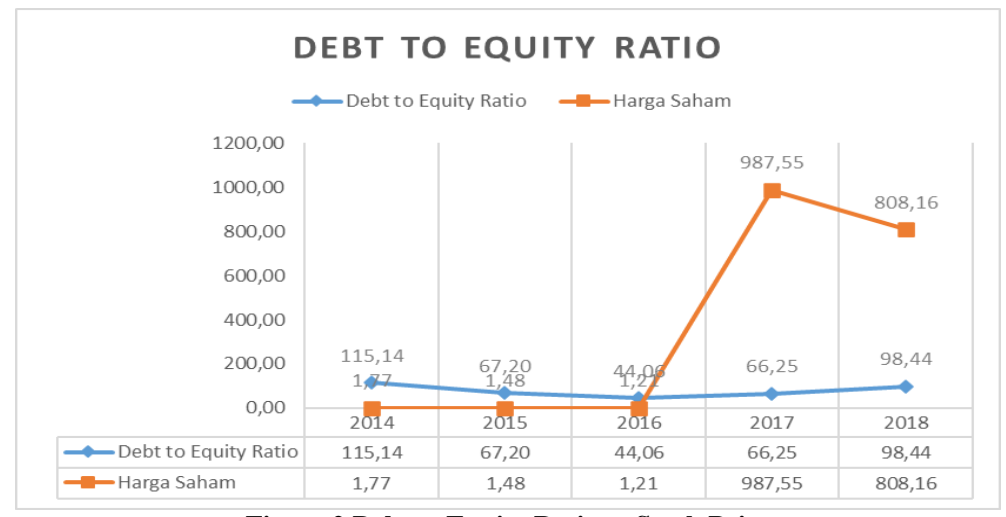

Figure 2.Debt to Equity Ratio to Stock Price 
Nurul Ramadhani Pauzi Harahap et.al. The effect of free cash flow, debt to equity ratio, working capital turnover and earnings per share on stock prices with stock beta as moderating variable in construction subsector companies listed on the IDX for the 2013-2019 period.

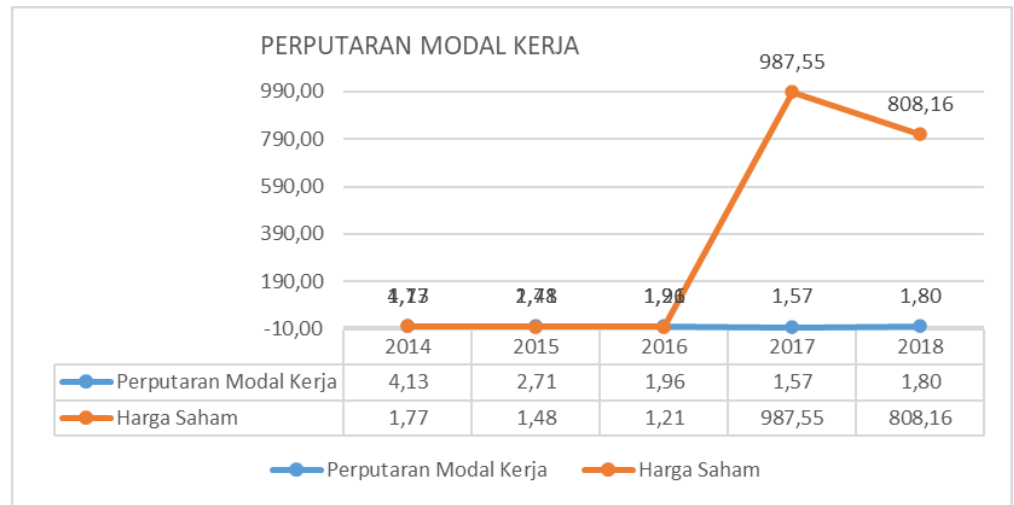

Figure 3.Working Capital Turnover to Share Price

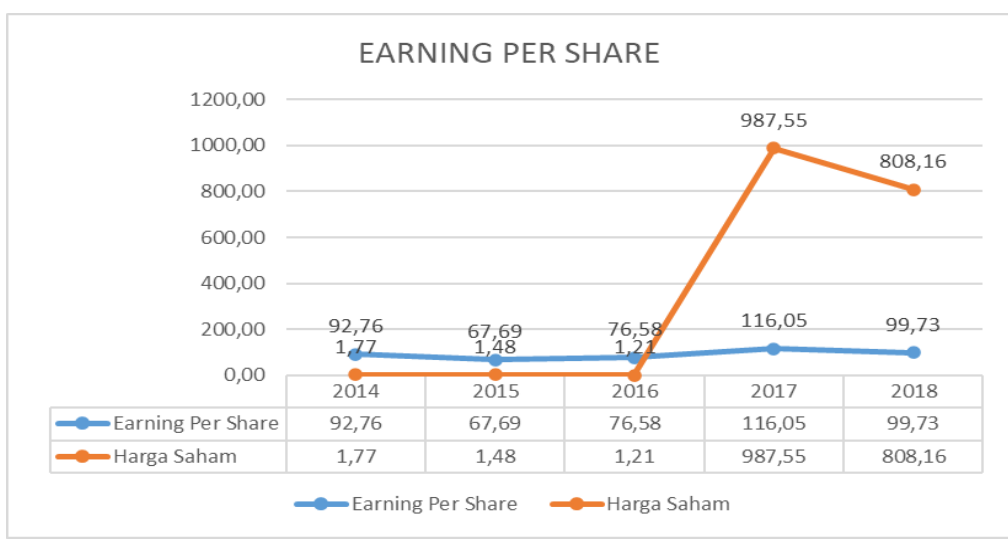

Figure 4.Earning Per Share to Share Price

Based on Figures 1-4 above, it can be seen that stock price fluctuations are visible. Based on the existing theory, if the Free Cash Flow, Working Capital Turnover, and Earning Per Share (EPS) increase, the stock price will also increase. Suppose the Debt to Equity Ratio decreases, the stock price increases. It does not occur in Free Cash Flow, Debt to Equity Ratio, Working Capital Turnover, and Earning Per Share (EPS) in Construction Sub-Sector Companies listed on the IDX. In the 20142018 period when free cash flow increased but stock prices decreased, the 2014-2016 Debt to Equity Ratio period decreased, but stock prices also decreased. In the 20162017 period, the Debt to Equity Ratio has increased, even though the stock price has also increased. Then for the 2016-2017 period, when working capital turnover decreased, stock prices rose. During the 2017-2018 period, working capital turnover increased, but stock prices decreased. Then in the 2015-2016 period, when Earning Per Share increased, the stock price decreased.

\section{Previous Research}

Several previous studies discussed the Effect of Free Cash Flow, Debt to Equity Ratio (DER), Working Capital Turnover, and Earning Per Share (EPS) on Stock Prices. Oktaryani et al. (2016) suggest that free cash flow has a positive and significant effect with an R2 value of $37.2 \%$ on stock prices. Contrary to the research of Samosir et al. (2017), which partially shows that Free Cash Flow does not affect stock prices. Then research from Chandra and Veronica (2018) shows that there is no significant effect between the Debt to Equity Ratio on stock prices. This research is in line with Sumantri (2020), Rusdiyanto (2020), and Safitri et al. (2020). In contrast to the results of Sari's research (2017), which shows the Debt to Equity Ratio (DER) has a significant negative effect with an R2 value of $19.54 \%$ on stock prices. This 
Nurul Ramadhani Pauzi Harahap et.al. The effect of free cash flow, debt to equity ratio, working capital turnover and earnings per share on stock prices with stock beta as moderating variable in construction subsector companies listed on the IDX for the 2013-2019 period.

result is in line with Marpaung \& Marpaung (2018) and Shalini (2020).

Then research from Setyardiani (2017) shows that the working capital turnover variable has a significant effect with an 2 value of $74.9 \%$ on stock prices. This result is in line with Marpaung \& Marpaung (2018). This study is not in line with Arista's research (2017) that working capital turnover has an insignificant negative effect on stock prices. Then research from Sari (2017) shows that Earning Per Share (EPS) has a significant positive effect with an R2 value of $73.10 \%$ on stock prices. These results are in line with the research of Sumantri (2020), Rusdiyanto (2020), and Safitri et al. (2020).

Based on the above phenomenon and the different results of previous studies, the researchers are interested in researching with the title "The Effect of Free Cash Flow, Debt To Capital Ratio, Working Capital Turnover and Earnings Per Share on Stock Prices With Stock Beta As Moderating Variables in Construction Sub-Sector Companies listed on the Indonesia Stock Exchange for the 2013 - 2019 Period."

\section{Framework}

Following the description of the background of the problem, literature review, and previous research, a conceptual research framework is prepared as follows:

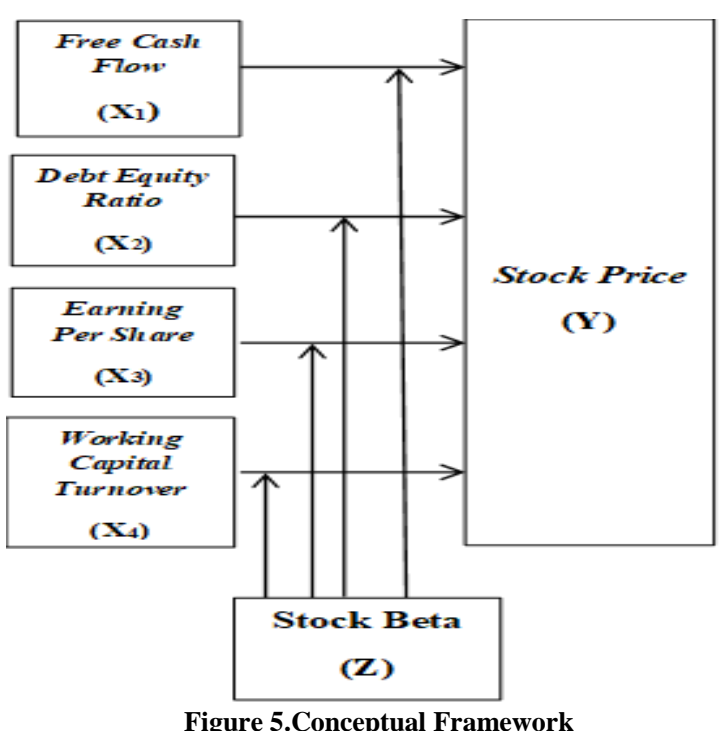

H1: Free Cash Flow (FCF) has a positive effect on Stock Prices.

H2: Debt to Equity Ratio (DER) has a negative effect on Stock Prices.

H3: Earning Per Share (EPS) has a positive effect on Stock Prices.

H4: Working Capital Turnover (WCT) has a positive effect on Stock Prices.

H5: Stock Beta moderates the relationship between Free Cash Flow (FCF) and Stock Price.

H6: Stock Beta moderates the relationship between Debt to Equity Ratio (DER) to Stock Price

H7: Stock Beta moderates the relationship between Earning Per Share (EPS) and Stock Price.

H8: Stock Beta moderates the relationship between Working Capital Turnover (WCT) and Stock Price.

\section{RESEARCH METHODS}

This type of research is causal associative research to determine the effect of Free Cash Flow, Debt to Equity Ratio (DER), Earning Per Share (EPS), and Working Capital Turnover (WTC) as independent variables on Stock Price as the dependent variable with Stock Beta as a moderating variable. The causal associative study analyzes the relationship between one variable and another to know how one variable affects other variables (Sugiyono, 2012). The data analysis method used in this study is a statistical analysis method using the E-Views 10 application. Data analysis performs by testing standard assumptions and testing hypotheses.

The method of determining the sample uses purposive sampling so that a sample of 10 companies is multiplied by five years of research so that 50 observations are obtained.

\section{RESULT AND DISCUSSION Panel Data Regression Model}

To analyze panel data, what must be done is to analyze the Common Effect Model (CEM), Fixed Effect Model (FEM), 
Nurul Ramadhani Pauzi Harahap et.al. The effect of free cash flow, debt to equity ratio, working capital turnover and earnings per share on stock prices with stock beta as moderating variable in construction subsector companies listed on the IDX for the 2013-2019 period.

and Random Effect Model (REM) to Random Effect Model Test

determine the appropriate model to use.

\section{Common Effect Model Test}

\begin{tabular}{ccccc}
\multicolumn{4}{c}{ Table 1.Common Effect Model Estimation Results } \\
Variable & Coefficient & Std. Error & t-Statistic & Prob. \\
\hline C & 560.2248 & 206.0071 & 2.719444 & 0.0084 \\
X1 & -0.000140 & 0.000127 & -1.101428 & 0.2748 \\
X2 & 74.34355 & 46.77809 & 1.589282 & 0.1168 \\
X3 & 1.214041 & 0.545610 & 2.225110 & 0.0296 \\
X4 & 2.923630 & 0.925332 & 3.159546 & 0.0024 \\
\hline \hline & & & & \\
R-squared & 0.202548 & Mean dependent var & 1163.114 \\
Adjusted R-squared & 0.153474 & S.D. dependent var & 1110.718 \\
S.E. of regression & 1021.936 & Akaike info criterion & 16.76554 \\
Sum squared resid & 67883009 & Schwarz criterion & 16.92614 \\
Log likelihood & -581.7937 & Hannan-Quinn criter. & 16.82933 \\
F-statistic & 4.127408 & Durbin-Watson stat & 0.654115 \\
Prob(F-statistic) & 0.004844 & & \\
\hline
\end{tabular}

Source: Processed with E-Views 10

From the regression results of common effect models, it is found that the coefficient value at X1 (Free Cash Flow) = 0.000140, X2 (Working Capital Turnover) = 74.34355, X3 (Debt to Equity Ratio) = 1.214041, X4 (Earning Per Share) = 2.923630 with an R-squared of 0.202548 .

\section{Fixed Effect Model}

\begin{tabular}{lcll}
\multicolumn{4}{c}{ Table 2.Estimated Results of Fixed Effect Models } \\
R-squared & 0.699381 & Mean dependent var & 1163.114 \\
Adjusted R-squared & 0.629594 & S.D. dependent var & 1110.718 \\
S.E. of regression & 675.9938 & Akaike info criterion & 16.04710 \\
Sum squared resid & 25590186 & Schwarz criterion & 16.49680 \\
Log likelihood & -547.6485 & Hannan-Quinn criter. & 16.22573 \\
F-statistic & 10.02170 & Durbin-Watson stat & 1.406059 \\
Prob(F-statistic) & 0.000000 & & \\
\multicolumn{4}{c}{ Source: Processed with E-Views 10 } \\
\end{tabular}

The regression results in Table 2 shows that the probability of each individual shows that the three variables, X1, X2, X3, and $\mathrm{X} 4$, are significant. R-squared shows 0.699381 . Meanwhile, the probability value of the F statistic is 0.000000 , which means that the model is very significant.

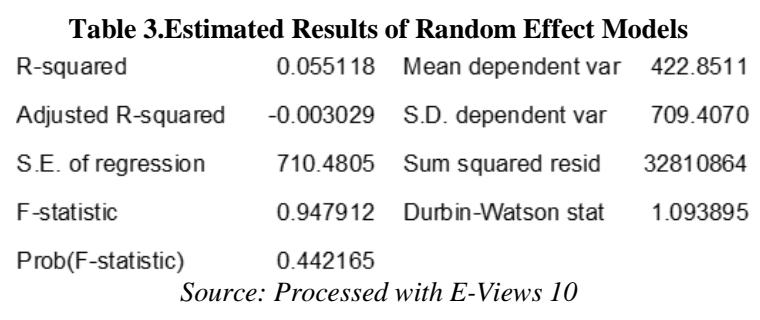

The Random Effect Models regression results show that the probability of the three variables, namely $\mathrm{X} 1, \mathrm{X} 2, \mathrm{X} 3$, and $\mathrm{X} 4$, is significant. R-squared shows 0.055118, and F-statistics shows 0.442165, which means the data is not significant.

\section{Model Estimation Selection Chow test}

Table 4.Chow Test

\begin{tabular}{lcrc}
\hline \hline Effects Test & Statistic & d.f. & Prob. \\
\hline \hline Cross-section F & 10.283448 & $(9,56)$ & 0.0000 \\
Cross-section Chi-square & 68.290379 & 9 & 0.0000 \\
\hline \multicolumn{4}{c}{ Source: Processed with E-Views 10} \\
\hline
\end{tabular}

Based on the table above, it shows that the probability value of 0.0000 is smaller than 0.05, so the Fix Effect Model (FEM) is better than the Common Effect Model (CEM).

\section{Hausman Test}

\begin{tabular}{|c|c|c|c|}
\hline \multicolumn{4}{|c|}{ Table 5.Hausman Test } \\
\hline Test Summary & Chi-Sq. Statistic & Chi-Sq. d.f. & Prob. \\
\hline Period random & 11.621976 & 4 & 0.0204 \\
\hline
\end{tabular}

The table above shows that the probability value $=0.0204$ is smaller than 0.05 , so the model that is feasible to use is the Fixed Effect Model (FEM).

The Langrange Multiplier (LM) test aims to see between the CEM or REM models. This test is needed when the results of the Chow test are CEM, and the results of the Hausman test are REM. In this study, the results of the Chow test were FEM, so there was no need for the LM test. 
Nurul Ramadhani Pauzi Harahap et.al. The effect of free cash flow, debt to equity ratio, working capital turnover and earnings per share on stock prices with stock beta as moderating variable in construction subsector companies listed on the IDX for the 2013-2019 period.

Hypothesis Test

\begin{tabular}{|c|c|c|c|c|}
\hline \multicolumn{5}{|c|}{ Table 6.Hypothesis Test Result } \\
\hline Variable & Coefficient & Std. Error & t-Statistic & Prob. \\
\hline FCF & -0.000140 & 0.000127 & -1.102603 & 0.2743 \\
\hline WCT & 74.67914 & 46.78738 & 1.596138 & 0.1153 \\
\hline DER & 1.211585 & 0.546327 & 2.217692 & 0.0301 \\
\hline EPS & 2.919592 & 0.927271 & 3.148587 & 0.0025 \\
\hline $\mathrm{C}$ & 559.0795 & 206.4935 & 2.707492 & 0.0087 \\
\hline R-squared & 0.201812 & Mean depe & endent var & 1163.114 \\
\hline Adjusted R-squared & 0.152693 & S.D. deper & ndent var & 1110.718 \\
\hline S.E. of regression & 1022.408 & Akaike info & criterion & 16.76646 \\
\hline Sum squared resid & 67945652 & Schwarz cı & riterion & 16.92706 \\
\hline Log likelihood & -581.8260 & Hannan-Q & uinn criter. & 16.83025 \\
\hline F-statistic & 4.108621 & Durbin-Wa & tson stat & 0.653394 \\
\hline Prob(F-statistic) & 0.004976 & & & \\
\hline
\end{tabular}

Source: Processed with E-Views 10

\section{Determinant Coefficient R2 (Goodness of Fit R2)}

Based on Table 6. above, the Rsquare value is 0.1201812 or $20.18 \%$. It means that the independent variables, namely free cash flow, debt to equity ratio (DER), working capital turnover, and earnings per share (EPS), can explain the stock price of $20.18 \%$, while other variables outside the model explain $79.82 \%$.

\section{Simultaneous Significance Test (F Test)}

Based on Table 6. above, it can be seen that the calculated $F$ value (4.11) > F table value (2.51), so it can be concluded that the independent variables jointly affect the dependent variable.

\section{Partial Test (T-Test)}

Based on Table 6. Above, it can be concluded that:

- Free Cash Flow Variable has a value of t-count $(-1.102603)<\mathrm{t}$-table $(1.66691)$, meaning that Free Cash Flow does not affect Stock Price.

- Working Capital Turnover variable has a value of t-count $(1.596138)<\mathrm{t}$-table (1.66691), meaning that Working Capital Turnover does not affect stock prices.

- The Debt to Equity Ratio variable has a value of t-count (2.217692) > t-table (1.66691), meaning that the Debt to Equity Ratio affects stock prices.
The Earning Per Share variable has a value of t-count (3.148587) > t-table (1.66691), meaning that Earning Per Share affects the stock price.

\section{Moderated Regression Analysis (MRA) Test}

Table 7.Stock beta moderates Free Cash Flow to Stock Price

\begin{tabular}{lrlrl} 
Variable & Coefficient & Std. Error & t-Statistic & Prob. \\
\hline \hline C & 1263.029 & 92.24905 & 13.69152 & 0.0000 \\
FCF (X1) & -0.000243 & 0.000100 & -2.420648 & 0.0187 \\
STOCKBETA (Z) & -346.2928 & 241.1418 & -1.436055 & 0.1565 \\
M1 (X1*Z) & 0.000482 & 0.000192 & 2.513572 & 0.0148 \\
\hline \hline \multicolumn{5}{c}{ Effects Specification } \\
\hline \hline Cross-section fixed (dummy variables) & \\
\hline \hline & & & \\
R-squared & 0.729083 & Mean dependent var & 1163.114 \\
Adjusted R-squared & 0.672048 & S.D. dependent var & 1110.718 \\
S.E. of regression & 636.0759 & Akaike info criterion & 15.91450 \\
Sum squared resid & 23061773 & Schwarz criterion & 16.33208 \\
Log likelihood & -544.0074 & Hannan-Quinn criter. & 16.08036 \\
F-statistic & 12.78305 & Durbin-Watson stat & 1.488257 \\
Prob(F-statistic) & 0.000000 & & \\
\hline & Source: Processed E-Views 10
\end{tabular}

Based on Table 7, the output results show that the moderating variable $(\mathrm{X} 1 * \mathrm{Z})$ indicates the t-statistic value of the moderating variable is 2.513572 , and the moderating probability is 0.0148 . This value is smaller than the expected significant level $(0.0148<0.05)$, where the $t$-statistic value is positive and significant. The R-square value of 0.729083 is greater than the previous 0.1201812. So Beta Stocks can strengthen the effect of free cash flow on stock prices.

\begin{tabular}{|c|c|c|c|c|}
\hline \multicolumn{5}{|c|}{ Table 8.Stock Beta moderates DER to Stock Price } \\
\hline Variable & Coefficient & Std. Error & t-Statistic & Prob. \\
\hline $\mathrm{C}$ & 1234.750 & 129.3839 & 9.543310 & 0.0000 \\
\hline DER $(\times 2)$ & -0.152842 & 1.064229 & -0.143618 & 0.8863 \\
\hline STOCKBETA (Z) & -224.8109 & 279.7745 & -0.803543 & 0.4250 \\
\hline M2 (X2^Z) & -0.052222 & 1.093585 & -0.047753 & 0.9621 \\
\hline \multicolumn{5}{|c|}{ Effects Specification } \\
\hline \multicolumn{5}{|c|}{ Cross-section fixed (dummy variables) } \\
\hline R-squared & 0.694310 & \multicolumn{2}{|c|}{ Mean dependent var } & 1163.114 \\
\hline Adjusted R-squared & 0.629954 & \multicolumn{2}{|c|}{ S.D. dependent var } & 1110.718 \\
\hline S.E. of regression & 675.6651 & \multicolumn{2}{|c|}{ Akaike info criterion } & 16.03526 \\
\hline Sum squared resid & 26021826 & \multicolumn{2}{|c|}{ Schwarz criterion } & 16.45283 \\
\hline Log likelihood & -548.2340 & \multicolumn{2}{|c|}{ Hannan-Quinn criter. } & 16.20112 \\
\hline F-statistic & 10.78862 & \multirow{2}{*}{\multicolumn{2}{|c|}{ Durbin-Watson stat }} & 1.450327 \\
\hline Prob(F-statistic) & 0.000000 & & & \\
\hline
\end{tabular}


Nurul Ramadhani Pauzi Harahap et.al. The effect of free cash flow, debt to equity ratio, working capital turnover and earnings per share on stock prices with stock beta as moderating variable in construction subsector companies listed on the IDX for the 2013-2019 period.

Based on Table 8. above, the output results show that the moderating variable $(\mathrm{X} 2 * \mathrm{Z})$ shows the $\mathrm{t}$-statistic value of the moderating variable, which is -0.047753 , and the moderating probability is 0.9621 . This value is greater than the expected significant level $(0.9621>0.05)$, where the t-statistic value is negative and insignificant. The R-square value of 0.694310 is greater than the previous 0.1201812 . Then the stock beta cannot strengthen the effect of DER on stock prices.

\begin{tabular}{lrrrr}
\multicolumn{5}{c}{ Table 9.Stock Beta moderates EPS against Stock Price } \\
Variable & Coefficient & Std. Error & \multicolumn{1}{c}{ t-Statistic } & Prob. \\
\hline \hline C & 1180.504 & 129.5763 & 9.110498 & 0.0000 \\
EPS (X3) & 0.392226 & 0.777464 & 0.504494 & 0.6159 \\
STOCKBETA (Z) & -232.1280 & 274.0017 & -0.847177 & 0.4004 \\
M3 (X3*Z) & -0.139886 & 0.941394 & -0.148594 & 0.8824 \\
\hline \hline \multicolumn{5}{c}{ Effects Specification } \\
\hline \hline Cross-section fixed (dummy variables) & \\
\hline \hline R-squared & 0.693122 & Mean dependent var & 1163.114 \\
Adjusted R-squared & 0.628516 & S.D. dependent var & 1110.718 \\
S.E. of regression & 676.9769 & Akaike info criterion & 16.03914 \\
Sum squared resid & 26122969 & Schwarz criterion & 16.45671 \\
Log likelihood & -548.3698 & Hannan-Quinn criter. & 16.20500 \\
F-statistic & 10.72846 & Durbin-Watson stat & 1.447040 \\
Prob(F-statistic) & 0.000000 & & \\
\hline \multicolumn{5}{c}{ Source: Processed E-Views 10 } \\
\hline
\end{tabular}

Based on Table 9. above, the output results show the moderating variable (X4 multiplied by $\mathrm{Z}$ ) indicating the t-statistic value of the moderating variable is 0.148594 and the moderating probability is 0.8824 . This value is greater than the expected significant level $(0.8824>0.05)$ where the t-statistic value is negative and insignificant. So Stock Beta cannot strengthen the effect of earnings per share/EPS on stock prices

Table 10.Stock Beta Moderates Working Capital Turnover

\begin{tabular}{crrrr}
\hline Variable & Coefficient & Std. Error & t-Statistic & Prob. \\
\hline \hline C & 1148.340 & 157.9513 & 7.270219 & 0.0000 \\
WCT $($ X4) & 29.55441 & 45.79483 & 0.645366 & 0.5213 \\
STOCKBETA (Z) & -54.95084 & 355.0223 & -0.154781 & 0.8775 \\
M4 (X4Z) & -87.80531 & 87.67738 & -1.001459 & 0.3208 \\
\hline \hline & Effects Specification \\
\hline \hline
\end{tabular}

Cross-section fixed (dummy variables)

\begin{tabular}{lrll}
\hline \hline R-squared & 0.695313 & Mean dependent var & 1163.114 \\
Adjusted R-squared & 0.631168 & S.D. dependent var & 1110.718 \\
S.E. of regression & 674.5557 & Akaike info criterion & 16.03197 \\
Sum squared resid & 25936451 & Schwarz criterion & 16.44955 \\
Log likelihood & -548.1190 & Hannan-Quinn criter. & 16.19784 \\
F-statistic & 10.83977 & Durbin-Watson stat & 1.399148 \\
Prob(F-statistic) & 0.000000 & & \\
& \multicolumn{3}{c}{ Source: Processed E-Views 10 }
\end{tabular}

Based on Table 10 above, the output results show the moderating variable (X3 times $\mathrm{Z}$ ), indicating the $\mathrm{t}$-statistic value of the moderating variable is -1.001459 , and the moderating probability is 0.3208 . This value is greater than the expected significant level $(0.3208>0.05)$, where the t-statistic value is negative and insignificant. The Rsquare value of 0.695313 is greater than the previous 0.1201812. Then the stock beta cannot strengthen the effect of working capital turnover on stock prices

\section{CONCLUSION}

Based on the results of data analysis and research discussion, the following conclusions can be drawn:

1. Free Cash Flow does not significantly affect stock prices in Construction SubSector Companies listed on the IDX in 2013 - 2019.

2. Debt to Equity Ratio (Debt to Equity Ratio) significantly influences stock prices in Construction Sub-Sector Companies listed on the IDX in 2013 2019.

3. Earnings per share (Earning Per Share) significantly influences share prices in Construction Sub-Sector Companies listed on the IDX in 2013 - 2019.

4. Working Capital Turnover does not significantly affect stock prices in Construction Sub-Sector Companies listed on the IDX in 2013 - 2019.

5. Beta Shares can moderate the relationship between Free Cash Flow and Share Prices in construction subsector companies listed on the IDX for 2013 - 2019.

6. Beta Shares can moderate the relationship between debt to equity ratio (Debt to Equity Ratio) to stock prices in construction sub-sector companies listed on the IDX for $2013-2019$.

7. Beta Shares can moderate the relationship between earnings per share (earnings per share) and share prices in construction sub-sector companies listed on the IDX for $2013-2019$. 
Nurul Ramadhani Pauzi Harahap et.al. The effect of free cash flow, debt to equity ratio, working capital turnover and earnings per share on stock prices with stock beta as moderating variable in construction subsector companies listed on the IDX for the 2013-2019 period.

8. Beta Shares can moderate the relationship between Working Capital Turnover and Share Prices in construction sub-sector companies listed on the IDX for $2013-2019$.

\section{Limitations of the Research}

The results of this study have several limitations, including:

Due to limited time and resources, this study only examines the scope of the construction sub-sector companies listed on the IDX so that the results of this study purely reflect the construction sub-sector companies listed on the IDX from 2013 2019. Future research needs to consider expanding the scope of the research to get a broader and more precise picture.

\section{Suggestion}

Based on the conclusions and limitations that have been found, the researcher provides several suggestions, including:

1. Companies should utilize and manage all the resources they have to the maximum in order to increase their business growth and also make investors more confident to invest in the company

2. For researchers, it is better to increase the number of samples by extending the observation period so that the results obtained can be used as a basis for predicting factors that affect stock prices.

\section{Acknowledgement: None}

\section{Conflict of Interest: None}

\section{Source of Funding: None}

\section{REFERENCES}

1. Arista, B., \& Oetomo, H. W. (2017). Pengaruh Perputaran Modal Kerja, Ukuran Perusahaan, Pertumbuhan Aset, Dan Profitabilitas Terhadap Harga Saham. Jurnal Ilmu Dan Riset Manajemen, 6(10).

2. Chandra, Stefani S. V. (2018). The Effect Of Cr, Der, Eps, Roa, And Sales Growth On
Stock Prices Of Manufacturing Companies. BILANCIA, 2(3), 343-354.

3. Darmadji, Tjiptono dkk. (2012). Pasar Modal di Indonesia- Pendekatan Tanya Jawab. Jakarta: PT. Salemba Empat.

4. Fabozzi F. J., dan Francis, J.C., 1977. "Stability Tests For Alphas and Betas Over Bull and Bear Market Conditions," Journal of Finance, 32.

5. Hery. (2009). Teory Akuntansi. Jakarta: Lencana.

6. Kasmir. (2008). Manajemen Perbankan, Edisi Revisi. PT Raja Grafindo Persada.

7. Kasmir. (2011). Analisis Laporan Keuangan. Jakarta: PT Rajawali Press.

8. Muiz, Muhammad Abdul (2016). Pengaruh Earning Per Share (EPS). Return On Asset (ROA) dan Dividen Payout Ratio DPR) terhadap Harga Saham, JOM Fekom Vol.3 N0.2

9. Lubis, C., Marpaung, B. S., \& Magdalena, A. (2018). Total Asset Turnover Effect, Working Capital Turnover, and Debt Ratio on Stock Price. The International Conference on Accounting and Management Science, 270.

10. Oktaryani, G. A. S., Sofiyah, S., P, I. N. N. A., Bisma, I. D. G., \& Mandra, I. G. (2016). Pengaruh Free Cash Flow Dan Leverage Terhadap Harga Saham Dengan Kebijakan Dividen Sebagai Variabel Intervening. Jurnal Ilmu Manajemen Dan Bisnis, 1(2), 113.

11. Ramadhan, W. A. (2016). Pengaruh Free Cash Flow, Investment Opportunity Set, Dan Sales Growth Terhadap Dividend Policy Pada Perusahaan Manufaktur Yang Terdaftar di Bursa Efek Indonesia. Jurnal Manajemen Bisnis Indonesia 5(2)

12. Rusdiyanto, D. (2020). The Effect Of Earning Per Share, Debt To Equity Ratio And Return On Assets On Stock Prices: Case Study Indonesian. Academy of Entrepreneurship Journal, 26(2), 1-11.

13. Safitri, K., Mertha, I. M., Gusti, N., Wirawati, P., \& Dewi, A. (2020). The Impact of Debt to Equity Ratio, Price Earning Ratio, Earning Per Share to The Stock Price On Banking Sectors Listed In INFOBANK15 index 2014-2018. American Journal of Humanities and Social Sciences Research (AJHSSR), 4(5), 49-56.

14. Samosir, A., \& Noviardy, A. (2017). Pengaruh Free Cash Flow, Profitability, Firm Size Dan Leverage Terhadap Harga 
Nurul Ramadhani Pauzi Harahap et.al. The effect of free cash flow, debt to equity ratio, working capital turnover and earnings per share on stock prices with stock beta as moderating variable in construction subsector companies listed on the IDX for the 2013-2019 period.

Saham Pada Perusahaan Pertanian Sub Sektor Perkebunan Yang Terdaftar Di BEI Alamat: Jln . Jend . A . Yani No . 12, Seberang Ulu I , Kota Palembang , Sumatera Abstract . Free.

15. Sari, Lili Angga. (2017). Pengaruh EPS, DER, PBV Dan NPM Terhadap Harga Saham Perusahaan Properti. Jurnal Ilmu Dan Riset Manajemen, 6(8), 1-15.

16. Setiawan, A., \& Sumantri, M. B. A. (2020). The Effect of Return On Equity (ROE), Debt Equity Ratio (DER), and Earning Per Share (EPS) on Share Prices in LQ45 Indexed Companies on the Indonesia Stock Exchange for the 2015 - 2018 Period. Technium: Romanian Journal of ..., 2(7), 209-221.

http://techniumscience.com/index.php/techn ium/article/view/2242

17. Setyardiani, D. W., \& Fuadati, S. R. (2017). Pengaruh DER , Profitabilitas Dan Perputaran Modal Kerja. Jurnal Ilmu Dan Riset Manajemen, 6(7).

18. Shalini, Witya. 2020. Pengaruh Struktur Kepemilikan dan Kinerja Keuangan Terhadap Nilai Perusahaan dengan Kebijakan Dividen Sebagai Variabel
Moderating pada Perusahaan Properti dan Real Estate yang Terdaftar di BEI Periode 2010-2018. Tesis. Universitas Sumatera Utara.

19. Sugiyono. (2014). Metode Penelitian Kuantitatif, Kualitatif dan R\&D . Bandung: Alfabeta.

20. Tandelilin, E. (2001). Beta Pada Pasar Bullish Dan Bearish: Studi Empiris Di Bursa Efek Jakarta. Jurnal Ekonomi Dan Bisnis Indonesia, 16(3), 261-272.

21. White, Gerald I. Sondhi, Ashwinpaul C. Fried, Dov. (2003). The Analysis and use of financial statements. $3^{\text {nd }}$ edition. Wiley.

How to cite this article: Nurul Ramadhani Pauzi Harahap, Yahya I, Nasution AA. The effect of free cash flow, debt to equity ratio, working capital turnover and earnings per share on stock prices with stock beta as moderating variable in construction sub-sector companies listed on the IDX for the 2013-2019 period. International Journal of Research and Review. 2021; 8(8): 244-253. DOI: https://doi.org/10.52403/ijrr. 20210834 